\title{
Epidermal cyst mimicking incision line metastasis
}

\begin{abstract}
Ramazan Gündoğdu', Erhan Ayhan², Tahsin Çolak
Epidermal cysts are cystic tumors lined with keratinized squamous layer and filled with keratin debris. Epidermal cysts may develop by implantation of surface epidermal layer into the dermis or subcutaneous tissue after trauma or surgical procedures. Cervix cancer spreads either directly or via the vascular and lymphatic systems. Distant skin metastasis of endometrium or cervix cancer is very rare. In this case report, a patient who had a history of cervix cancer operation 11 years ago and presented with a mass that mimicked incision line metastasis and was histopathologically diagnosed with epidermal cyst is presented.

Keywords: Epidermal cyst, cervix cancer, incision line metastasis
\end{abstract}

Cite this paper as: Gündoğdu R, Ayhan E, Çolak T. Epidermal cyst mimicking incision line metastasis. Turk J Surg 2017; 33(2): 133-134

'Clinic of General Surgery, Tokat Zile State Hospital, Tokat, Turkey ${ }^{2}$ Clinic of Dermatology, Tokat Zile State Hospital, Tokat, Turkey ${ }^{3}$ Clinic of General Surgery, Mersin University School of Medicine, Mersin, Turkey

Address for Correspondence Ramazan Gündoğdu e-mail: drramazang@gmail.com

Received: 14.10 .2014

Accepted: 26.12.2014

Available Online Date: 02.07.2015

C) Copyright 2017

by Turkish Surgical Association

Available online at

www.turkjsurg.com

\section{INTRODUCTION}

Epidermal cysts are cystic tumors containing keratin surrounded by keratinized squamous epithelium (1). Epidermal cysts are mostly located in the palms and fingers, while they can be detected in any part of the body (2). Acquired epidermal cysts are related with implantation of superficial epidermal tissue into the dermis or subcutaneous tissue after trauma or surgical intervention (2). Cervical cancer spreads via direct invasion, hematogenous and lymphatic dissemination (3). Skin metastasis of endometrium and cervical cancer is very rare (4).

Herein we report a patient, with a history of cervical cancer surgery 11 years ago, who was diagnosed with a calcified proliferative epidermal cyst that mimicked incision line metastasis.

\section{CASE PRESENTATION}

A 63-year-old female patient has been admitted to a health institution due to abnormal uterine bleeding in 2003. Her cervical biopsy has revealed squamous cell carcinoma. The patient has undergone total abdominal hysterectomy, bilateral salphingoooferectomy and pelvic paraaortic lymph node dissection. Histopathologic examination has been reported as squamous cell carcinoma and she has received 6 cycles of chemotherapy and radiotherapy. No additional problems have been identified in routine oncologic controls since 2003. The patient, who had stiffness and scarring in the incision line for about 2 months, presented to our hospital dermatology outpatient clinics. On dermatologic examination, a $2.5 \times 2 \mathrm{~cm}$ in diameter, irregular bordered, circumferentially hyperemic, infected, ulcerated, painless semimobile mass was observed in the left paramedian incision scar. The patient was consulted to general surgery and an infected tumor metastasis could not be ruled out. An oral-intravenous contrast enhanced computed tomography was obtained, which revealed scar tissue in the lower left part of the abdomen secondary to the surgical procedure along with nodular skin thickening and contrast enhanced calcified areas at this level, and tumor metastasis could not be ruled out (Figure 1).

No abnormality was detected in her laboratory parameters. An operation was planned because the patient's findings could not be differentiated from tumor metastasis. Total excision was performed by obtaining a macroscopic intact surgical margin to include the old operation scar and the infected mass. The patient was discharged without any problems on the first day after the operation. Histopathological examination revealed ruptured mixed inflammatory proliferative epidermal cyst.

A detailed informed patient consent form was obtained for the presentation of this case.

\section{DISCUSSION}

Epidermal cysts are most common in the young and middle ages, with equal frequency among men and women. Clinically they appear as painless, slow-growing, regular bordered lesions. Symptoms may occur in 6 months or in 20 years. The malignant conversion is rare. Macroscopically, they are usually greater than $3 \mathrm{~cm}$ in size (5). Cervical cancer is the second most common cancer type among women in 

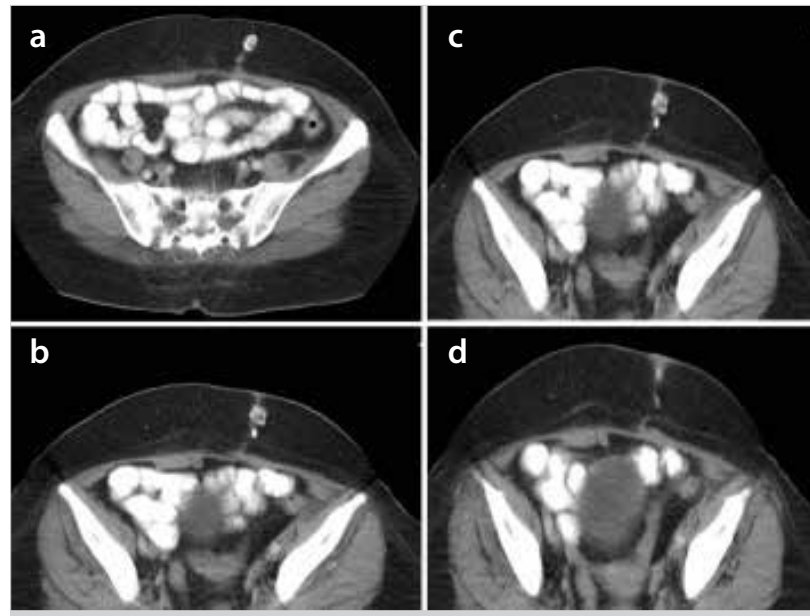

Figure 1. a-d. Mass lesion with nodular calcified zones in the incision line

the world. In Turkey, it is the $9^{\text {th }}$ most common cancer among women and is ranked $13^{\text {th }}$ among causes of cancer-related death (6). Cervical cancer spreads via direct invasion, hematogenous and lymphatic dissemination (3). Skin metastasis of endometrium and cervical cancer is very rare. The incidence ranges between 0.1 and 2\% (4). There are reports in the literature that the interval between cervical cancer surgery and diagnosis of skin metastasis may be 1-70 months (7). The most common type of cancers with skin incision metastasis have been reported as colon, kidney and bladder cancer (8).

Our patient had a history of surgical operation 11 years ago. The location of the lesion on the incision line, the oncologic history of the patient, the ulceration and induration on the mass and the skin led to a suspicion of tumor metastasis.

Acquired epidermal cysts develop with implantation of superficial epidermal tissue into the dermis or subcutaneous tissue after trauma or surgical intervention (2). The lesions become visible after a traumatic event in a period of months to years (9). These lesions most commonly occur in the distal fingers of males and females aged 30 to 40 years (10). In the literature, epidermoid cyst that developed after 5 years in a patient who has undergone mastoidectomy due to cholestatoma (1), and epidermal cyst cases in the incision line following ear surgery has been reported (2).

\section{CONCLUSION}

The rare incision line epidermal cyst may mimic tumor metastasis in patients with a history of tumor surgery. It should be kept in mind that chronic wounds and masses formed in the incision line may rarely be tumor metastasis while they may be related to benign causes such as epidermal cysts. Histopathologic examination should be performed for their differential diagnosis.

Informed Consent: Written informed consent was obtained from patient who participated in this case.

Peer-review: Externally peer-reviewed.

Author Contributions: Concept - R.G., E.A.; Design - R.G.; Supervision - R.G.; Funding - R.G.; Data Collection and/or Processing - R.G.; Analysis and/or Interpretation - R.G., E.A.; Literature Review - R.G., E.A.; Writer R.G., T.Ç.; Critical Review -T.Ç.

Conflict of Interest: No conflict of interest was declared by the authors.

Financial Disclosure: The authors declared that this study has received no financial support.

\section{REFERENCES}

1. Ülkü C, Uyar Y, Kocaoğullar Y, Avunduk MC. latrogenic epidermal inclusion cyst of the parapharyngeal space: Unusual complication of ear surgery. Skull Base 2004; 14: 47-51. [CrossRef]

2. Özcan $\mathrm{K}$, Dere $\mathrm{H}$, Özcan I. An epidermal cyst in the parotid gland following ear surgery: A case report. B-ENT 2006; 2: 193-195.

3. Arısan K. Kadın Hastalıkları, Jinekoloji. Uterus kanserleri 3. baskı İstanbul 1991; 647-685.

4. Basu B, Mukherjee S. Cutaneous metastasis in cancer of the uterine cervix: A case report and review of the literature. J Turk Ger Gynecol Assoc 2013; 14: 174. [CrossRef]

5. Kılıç MV, Uyar Y, Kuzdere M, Yıldırım G, Kaman B, Özcan D. An epidermal cyst in parotid gland: A case report. Medical Journal of Okmeydanı 2011; 27: 59-61.

6. Yavuzer D, Karadayı N, Erdağı A, Salepçi T, Baloğlu H, Dabak R. HPV typing with PCR in cervical cancerous and precancerous lesions. J Kartal Tr 2009; 20: 1-6.

7. Özmen B, Sükür YE, Atabekoğlu C, Güngör M. Prolonged survival in a squamous cell carcinoma of the cervix after late skin metastasis to incision site: A case report. J Turk Ger Gynecol Assoc 2009; 10: 175-177.

8. Srivastava K, Singh S, Srivasta M, Srivasta AN. Incisional skin metastasis of a squamous cell cervical carcinoma 3.5 years after radical treatment: A case report. Int J Gynecol Cancer 2005; 15: 11831186. [CrossRef]

9. Nahra Mitchell E, Bucchieri John S. Ganglion cysts and other tumor releated conditions of the hand and wrist. Hand Clinics 2004; 20: 249-260. [CrossRef]

10. Edward A. Athanasian. Bone and soft tissue tumors, Green's Operative Hand Surgery, Elsevier; 2005. p. 2211-2264. 